\title{
A Multilingual Thematic Picture Dictionary for Assisting Sixth Grade Elementary School Students' Literacy
}

\author{
N.K.P. Adnyani ${ }^{1 *}$, N.M. Ratminingsih ${ }^{2}$, I.G. Budasi ${ }^{3}$ (D) \\ 1,2,3 Ganesha University of Education, Bali, Indonesia
}

\section{A R T I CLE I N F O}

Article history:

Received July 24, 2020

Revised July 27, 2020

Accepted September 18, 2020

Available online May 25, 2021

Kata Kunci:

Kamus, Media Pembelajaran,

Literasi

Keywords:

Dictionary, Learning Media,

Literacy

DOI:

http://dx.doi.org/10.23887/jpbi. v8i2.27507

\section{A B S T R A C T}

Indonesia is known for having low literacy skills. Students' literacy skills are low because schools do not provide enough media to help students' literacy skills, especially dictionaries. This study aims to develop a multilingual thematic illustrated dictionary to assist sixth-grade elementary school students' literacy. This has an impact on student learning outcomes are low. In developing the dictionary, this study applies the Design and Development (D\&D) using four instruments to collect data: observation sheets, interview guides, questionnaires, and expert assessments. The subjects of this study were teachers and students from elementary schools in urban and rural areas in Buleleng Regency, North Bali. The results show that this dictionary is relevant to the eleven criteria of a good multilingual thematic illustrated dictionary. This dictionary is also categorized as an excellent medium of 10 themes with words and sentences in three languages and authentic pictures. Thus, multilingual thematic illustrated dictionaries are a helpful medium for students and teachers to develop literacy skills. This research implies that students in learning can use the developed dictionary. This is an open access article under the CC BY-SA license.
Copyright ( 2021 by Author. Published by Universitas Pendidikan Ganesha. This is an open access article under the CC BY-SA license.
Copyright ( 2021 by Author. Published by Universitas Pendidikan Ganesha.

\begin{abstract}
Indonesia dikenal memiliki kemampuan literasi yang rendah Kemampuan literasi siswa yang rendah disebabkan karena sekolah tidak menyediakan media yang cukup untuk membantu kemampuan literasi siswa khususnya kamus. Hal ini berdampak pada hasil belajar siswa yang rendah. Penelitian ini bertujuan untuk mengembangkan kamus bergambar tematik multibahasa untuk membantu literasi siswa kelas enam sekolah dasar. Dalam mengembangkan kamus, penelitian ini menerapkan metode esain dan Pengembangan $(D \& D)$ dengan menggunakan empat instrumen untuk penilaian ahli. Subjek penelitian ini adalah guru dan siswa dari sekolah dasar di daerah perkotaan dan pedesaan di Kabupaten Buleleng Bali Utara. Hasilnya menunjukkan bahwa kamus ini sangat relevan dengan sebelas kriteria kamus bergambar tematik multibahasa yang baik. Kamus ini juga dikategorikan sebaga media yang sangat baik yang terdiri dari 10 tema dengan kata dan kalimat dalam tiga bahasa dan gambar autentik. Dengan demikian, kamus bergambar tematik multibahasa merupakan media yang bermanfaat bagi siswa dan guru untuk mengembangkan keterampilan literasi. Implikasi penelitian ini yaitu kamus yang dikembangkan dapat digunakan oleh siswa dalam belajar.
\end{abstract}

\section{INTRODUCTION}

English becomes more important in recent years due to the use of English as an International language for doing communication, especially in an international context (Kamelia, 2019; Sun et al., 2021; Wong \& Russak, 2020). To involve and compete globally requires a higher quality of human resources which can be reached by developing literacy (O’Brien et al., 2020; Wusqo et al., 2021). Simply, literacy is defined as the ability to read and write. Literacy can lead children to have prosperity in the community (Beck et al., 2021). Literacy will direct children to make their world to be meaningful (Allan et al., 2018; Liang et al., 2021). It means that every activity done by children will have purpose and value. Being literate does not only lead people to actively participate in international activities, but it also leads people to be successful in school and life (Gonzalves, 2021; Piasta et al., 2021). Therefore, developing literacy skills is necessary to be done as a way to increase the quality of human resources as well as assist children to be successful learners.

However, Indonesia is known for having low literacy skills (Sari, 2020; Suryani et al., 2021). The result of the Program for International Student Assessment (PISA) 2015 shows that Indonesia is ranked $64^{\text {th }}$ out of the 70 countries which means the literacy skills of Indonesian children are lower than children in other countries (Lia, 2015). Indonesia is also categorized as the E-9 country along with 8 other countries which indicate that illiterate adults and out-of-school children can be found in Indonesia (Jessica et al., 2017). As a result, Indonesia is considered unable to compete globally. This has resulted in Indonesia being considered unable to compete globally. In addition, the current problem is the lack of media that can facilitate students in improving literacy 
skills. Based on the observations made at SDN 3 Banjar Jawa as representatives of schools in urban areas and SDN 1 Busungbiu as representatives of schools in rural areas. The problem found is that the school does not provide enough media to help students' literacy skills, especially dictionaries. Students only learn from the teacher's explanation and worksheets. This causes students to feel less interested in learning.

Three basic factors cause low literacy skills, such as factors from parents who become children's first teachers, the kind of media used by the teacher to support students learning process, and students' motivation to learn English (Falloon, 2020; Piasta et al., 2021). The other factors that cause low literacy skills, such as limited reading sources in schools, students' classroom environment, and students' difficulties in concentrating while reading. Hence, it can be inferred that low literacy skills are caused by external and internal factors from children surrounding (Polizzi, 2020; Suryandari et al., 2018). From those factors causing the low literacy skills, it is better to start enhancing literacy in young learners. Young learners are children around 3 to 12 years old (Lau \& Li, 2019; Muhonen et al., 2020). Children would be able to learn a new language easier. Children who learn a foreign language at an earlier age are alleged to have a better chance to be a proficient learner since their brain is programmed flexibly to obtain a new language naturally (Liyana \& Kurniawan, 2019a; Trisnanti et al., 2018). English is better to be introduced at an early age because the faster it is taught the better the results will be. However, it should be known that young learners are difficult to learn abstract concepts (Daunic et al., 2021; Korat et al., 2021). They need a visualization for understanding something. Young learners also love to play, learn best from their experiences and like to learn when the learning is meaningful and interesting (Alat \& Dedeoğlu, 2013; Charles et al., 2018). Considering those characteristics of young learners, thus the existence of media is necessary to assist the development of their literacy skills.

Instructional media is considered an appropriate medium for young learners (Maijarern et al., 2018; Wulandari et al., 2019). The instructional media can be used to avoid boredom, clarify ideas, stimulate students' learning motivations, save time, increase interest, hold attention, and make the learning process more interactive (Abror et al., 2020; Fartina et al., 2019). The instructional media can build a possible direct interaction between students and the environment. Instructional media into three types, namely visual media, audio media, and audiovisual media (Batubara \& Batubara, 2020; Budiman, 2016; Candra Lestari, 2018). From those three types of instructional media, visual media is suitable for young learners because it can be used to clarify abstract concepts (Puspita et al., 2016). The type of visual media that will be developed is printed media which is the dictionary. Dictionary is a media that commonly contains a list of words with their meaning and illustration that cannot be found on the other type of books (Li et al., 2021; Tong et al., 2021). The vocabularies which are provided in the dictionary are also considered as an important component of literacy. By using the dictionary, students would be able to increase their English understanding by finding the meaning of the word that they are confused with (Mahdi, 2018; Parvareshbar \& Ghoorchaei, 2016). They also can increase their writing skills and learn the language independently. Thus, the dictionary can be a beneficial medium to assist students' literacy skills as well as increase their English vocabulary.

The dictionary that is developed is a multilingual thematic picture dictionary. A multilingual thematic picture dictionary refers to a dictionary with three languages (English-Bahasa Indonesia-Balinese) that is arranged thematically based on students' English syllabus and equipped with authentic pictures. There are eleven criteria of a good multilingual thematic picture dictionary which are taken from each characteristic of the multilingual dictionary, thematic dictionary, and picture dictionary (Macaro \& Tian, 2015; Zhang et al., 2020). namely; (1) the dictionary has more than two languages, (2) the dictionary consists of words of the language source that are explained with their equivalents in more than two languages, (3) the dictionary should consist of simple words that come from a certain theme, (4) the dictionary consists of words with its sentences in each vocabulary, (5) this dictionary is arranged thematically with pictures linked to words of each theme, not alphabetically, (6) the dictionary should be made with more picture and fewer word, (7) the dictionary should be light and easy to hold for the young learner, (8) the dictionary's entries should be arranged alphabetically based on themes, (9) the dictionary's entries should be based on everyday experience and close environment, (10) the dictionary should use appropriate and authentic (concrete) picture, (11) the dictionary' picture should be positive, clear, and colorful. Based on those criteria, the dictionary will be evaluated whether it meets the criteria of a good multilingual thematic picture dictionary or not.

Moreover, several previous studies conducted studies about developing dictionaries. Those studies emphasized using themes in developing the list of words. The findings of previous research stated that the dictionary was developed to assist students in learning (Febriansyah et al., 2020; McCabe et al., 2019). Other research findings also state that dictionaries make it easier for students to understand the meaning of a word (Febriansyah et al., 2020; Sehgal et al., 2021). From those previous studies, the novelties of the current study are in terms of the aim of the study, the languages used in the dictionary, the sentences provided in the dictionary, and the subjects for which to whom the dictionary is intended. Thus, the multilingual thematic picture dictionary as the product of this study has novelties from those developed dictionaries by previous studies. This study 
aimed to develop a multilingual thematic illustrated dictionary to assist literacy in sixth-grade elementary school students. It is hoped that this dictionary can improve the literacy of elementary school students.

\section{METHOD}

This study applied the Design and Development method proposed by Richey and Klein which consisted of four stages (ADDE), namely; Analysis, Design, Development, and Evaluation (Tegeh \& Kirna, 2010). The data about students' needs in developing their literacy skills were collected by using an adapted and modified need analysis model by Hutchinson and Waters which consisted of target situation and learning needs. Then, there were five steps in developing the dictionary which was taken from the adapted and modified steps by Chaer namely; designing dictionary (decided the aim and equipment of the dictionary), developing corpus data (listed words), filling and serving data (filtered the list of words), processing data (checked the relevance of the words with basic competencies and themes in the syllabus), and giving meaning (gave meaning to the words) (Tegeh \& Kirna, 2010).

The subjects of this study were teachers and sixth-grade students from SDN 3 Banjar Jawa as the representative of urban elementary school and SDN 1 Busungbiu as the representative of rural elementary school. The subjects were chosen by using a purposeful sampling technique. Moreover, the data were collected through conducting observation, interview, questionnaire, and document analysis. In document analysis, the document was a sixth-grade English syllabus. Meanwhile, the instruments were an observation sheet, interview guide for teachers and sixth-grade students, questionnaire for sixth-grade students, and expert judgment. Moreover, there were nine procedures of data collection, namely: collecting preliminary data through informal observation and interviews, creating instrument, conducting observation, conducting the interview, conducting questionnaires, conducting document analysis, designing the draft of the dictionary, developing the draft into a final product, and evaluating the product.

The observation was used to collect data about the existence of dictionaries at library schools (library observation) and EFL classrooms as well as the use of dictionaries in the teaching-learning process (classroom observation). The interview was used to collect data about target situations, particularly teachers' and students' necessities, lacks, and wants in the teaching-learning process. The questionnaire was utilized to collect data about learning needs which focused only on how (methodology), what (media), and who (students' learning style). The document analysis was employed to review the sixth-grade English syllabus to collect themes for developing the dictionary. Moreover, there were two types of expert judgments used in this study, namely; (1) content validity judgment which focused on judging the content of dictionary based on eleven criteria of a good multilingual thematic picture dictionary, and (2) quality judgment which focused on rating the quality of the dictionary based on leven criteria of a good multilingual thematic picture dictionary.

There were two kinds of data; qualitative and quantitative. The qualitative data were obtained from observation, interview, questionnaire, and document analysis. Meanwhile, the quantitative data were attained from expert judgment. The result of content validity judgment was analyzed by using Gregory Formula (Nurkancana \& Sunartana, 1992). The first table which was the Gregory formula would show whether the contents of the dictionary were relevant or not to eleven criteria of a good multilingual thematic picture dictionary from the result of both judges.

Table 1. The Nurkancana and Sunartana formula (Nurkancana \& Sunartana, 1992).

\begin{tabular}{cc}
\hline Score & Criteria \\
\hline $\mathrm{X} \geq \mathrm{Mi}+1.5 \mathrm{Sdi}$ & Excellent \\
$\mathrm{Mi}+0.5 \mathrm{Sdi} \leq \mathrm{X}<\mathrm{Mi}+1.5 \mathrm{Sdi}$ & Good \\
$\mathrm{Mi}-0.5 \mathrm{Sdi} \leq \mathrm{X}<\mathrm{Mi}+0.5 \mathrm{Sdi}$ & Average \\
$\mathrm{Mi}-1.5 \mathrm{Sdi} \leq \mathrm{X}<\mathrm{Mi}-0.5 \mathrm{Sdi}$ & Below Average \\
$\mathrm{X}<\mathrm{Mi}-1.5 \mathrm{Sdi}$ & Poor \\
\hline
\end{tabular}

The table above was used to categorize the quality of the dictionary from the total score given by the expert judges and users. The $\mathrm{X}$ refers to mean. The Mi refers to ideal mean. The Sdi deals with standard deviation. To get MI, it should be 1/2 (Score max + Score Min) while Sdi should be 1/3 (Mi). In the quality rubric, there were scale ranges which were started from 1 as the minimum score to 5 as the maximum score. Since there were eleven criteria, thus the accumulated minimum score was 11 while the maximum score was 55 . Thus, the score of Mi was $1 / 2(55+11)=33$ while Sdi was $1 / 3(33)=11$. 


\section{RESULT AND DISCUSSION}

\section{Result}

The result of the observation at the SDN 3 Banjar Jawa and SDN 1 Busungbiu showed that their school libraries did not have multilingual thematic picture dictionaries. In the classroom, teachers and some students from both schools had a dictionary (bilingual dictionary or bilingual picture dictionary), but the students were the ones who used the dictionary during the learning process. It was because the students realized the importance of having and using a dictionary for themselves in learning English. Based on the teachers' interview, the teachers from both schools explained that they did not use a dictionary to teach English vocabulary because not all students had a dictionary. The schools also did not have enough dictionaries for all students, thus not all students can read the dictionary or use it during the learning process. Based on the students' interviews, it was found that not all students had a dictionary. Those who had a dictionary would bring theirs independently without any command from the teachers. Although the teachers did not use a dictionary to teach vocabulary, students said that they were understood from the way the teacher explained the vocabulary through writing some vocabulary on the blackboard, using an English textbook or student's worksheet, explaining the vocabulary in front of the class, and mentioning things in the class. However, if students were confused with the new vocabularies, they would find the meaning of the new vocabularies in their dictionary. It could increase their vocabulary and English understanding.

Furthermore, based on the result of the questionnaire, the statements number 1-5 were about the methodology used in learning English, such as playing games (96\%), listening to English songs (77\%), observing pictures $(89 \%)$, watching the video $(80 \%)$, and listening to teacher's explanation $(87 \%)$. The result showed that most students liked to play the game in learning English. It was related to Scott and Ytreberg's (1990) statement that young learners loved to play. The statements number 6-10 were about the use of media in learning English, such as English textbook (84\%), students' worksheet (68\%), dictionary (89\%), outline (80\%), and exercise $(79 \%)$. From the result, it was found that most students liked to use a dictionary as the media that can support them in learning English. This result was also related to the result of questionnaire number 11 in which $98 \%$ of students needed a dictionary in learning English. From both results, it was found that a dictionary was a necessary medium for learning English. Thus, it can be concluded that sixth-grade elementary school students needed a dictionary as a medium that can assist students to understand the meaning of words as well as develop their literacy skills.

Based on the sixth-grade elementary school students' need analysis, it was found that the dictionary was an appropriate media needed by the students in developing their literacy skills. Thus, this current study developed a multilingual thematic picture dictionary for sixth-grade students. The multilingual thematic picture dictionary was already developed based on the adapted and modified steps in developing dictionary by Chaer which consisted of five steps, such as designing dictionary, developing corpus data, filling and serving data, processing data, and giving meaning. The result was in the form of a dictionary draft which contained 10 themes based on the sixth-grade elementary school students' English syllabus. From those ten themes, the list of words in three languages (English-Bahasa Indonesia-Balinese) was developed which equipped with an example of sentences in three languages (English-Bahasa Indonesia-Balinese) and authentic picture for each word. Thus, the draft of the multilingual thematic picture dictionary was following the definition of the multilingual dictionary, thematic dictionary, and picture dictionary.

The next step was about developing the multilingual thematic picture dictionary draft into a final product. There were two steps in developing the dictionary draft, such as making dictionary cover and dictionary contents. In total, the multilingual thematic picture dictionary consisted of 94 pages. Then, the dictionary contents were judged by using content validity judgment. There were two expert judges in content validity judgment. The first expert was an English-Bahasa Indonesia expert and the second expert was a Balinese expert. The result of the content validity judgment showed that the dictionary was highly relevant with eleven criteria of a good multilingual thematic picture dictionary. However, the dictionary also had minor revisions in terms of cover, word, sentence, and picture. In terms of cover, there were two pictures used in the cover that was revised because one picture did not completely represent Balinese context as the indication of Balinese languages and one picture did not represent a sports figure from students' close environment. It would be better if the cover used pictures that had a relation with the students' environment. The total of the revision of the pictures in the dictionary was 44 words. The 42 pictures were revised because they did not represent students' close environment, the lion picture did not represent the sentence, and the policeman picture did not represent the image of a police officer. This revision was related to the criteria of a good multilingual picture dictionary.

Moreover, the words in the dictionary were also revised. In total, two words were removed and one word was added to the dictionary. The words were removed because one word was inappropriate for sixth-grade students and one word did not suitable with the theme. Meanwhile, one word was added to increase the number of words in one of the themes. Besides, the sentence in the dictionary was also revised. In total, nine sentences 
were revised. The sentences were revised because of a typographical error, English grammatical error, Balinese grammatical error, and irrational sentence. After doing some revisions, the dictionary consisted of 98 pages including the references of the pictures.

After revising the dictionary contents, the dictionary was judged to rate the quality of the dictionary by using quality judgment. The total score which was given by the first expert judge was 51 which categorized as excellent. The total score which was given by the second expert judge was 51 which categorized as excellent. The total score which was given by the third expert judge was 53 which categorized as excellent. The total score which was given by the first user was 53 which categorized as excellent. The total score which was given by the second user was 53 which categorized as excellent. Based on those total scores, it can be concluded that the multilingual thematic picture dictionary was categorized as an excellent media. A multilingual thematic picture dictionary is categorized as an excellent medium due to several factors as follows.

\section{Discussion}

First, the multilingual thematic picture dictionary is an excellent medium because its use is essential. The teachers cannot deny that dictionaries are essential for teaching English because dictionaries provide word lists. Dictionaries are reference books that generally contain lists of words and their meanings and illustrations that cannot be found in other types of books (Tong et al., 2021; Zhang et al., 2020). The dictionary also contains example sentences that will help students to understand the meaning of words clearly. Students can learn new vocabulary while at school and home using a dictionary (Alam \& Lestari, 2020; Liyana \& Kurniawan, 2019b). Using a dictionary, students can add to their vocabulary from the list of words available in the dictionary. Thus, by using a dictionary, students will learn English concretely and visualize and use their senses to learn English. In addition, dictionaries can also help students to develop their literacy skills. The vocabulary available in the dictionary is considered an essential component in developing literacy skills (Purnama et al., 2021; Sadaf \& Johnson, 2017). Dictionaries can help students to build their writing skills because students have an extensive vocabulary.

Second, the multilingual thematic picture dictionary is categorized as an excellent medium because it can help students learn. The dictionary also provides accurate pictures as word visualizations to help students understand words. The developed dictionary can be enjoyable as a game so that students are thrilled. Students like to learn when learning is exciting and meaningful, such as playing games (Greipl et al., 2020; Hwang et al., 2012). Therefore, students need media that can help them understand the meaning of the words used during the game (Bartel \& Hagel, 2014; Simbolon \& Satria, 2016). This is related to statements number 6-10 about the use of media in learning English and statement number 11 about student learning styles. Thus, dictionaries can be used to help students learn English clearly, especially elementary-level learners.

The findings of previous studies also stated that the development of dictionaries was urgently needed to assist students in learning new languages (McCabe et al., 2019; Tong et al., 2021). Other studies also state that dictionaries will facilitate students' learning (Majid et al., 2012; Sehgal et al., 2021; Zhang et al., 2020). However, the product of the current study had differences from those previous studies. The multilingual thematic picture dictionary was not only developed for helping sixth-grade students to learn English but also assisting their literacy skills. The dictionary also had three languages namely English - Bahasa Indonesia - Balinese which were different from the languages of the previous studies dictionary. The dictionary provided sentences in those three languages to help the students understand the context of the word while those previous studies dictionary only provided words and pictures. Moreover, the dictionary was specifically developed for sixth-grade students which can be used whether by urban or rural elementary schools. Thus, the product which was a multilingual thematic picture dictionary had novelties from those developed dictionaries by previous studies.

\section{CONCLUSION}

Based on the result of quality judgment from the expert judges and users, it was found that the dictionary was categorized as excellent media. Thus, the multilingual thematic picture dictionary was categorized as excellent media for assisting sixth-grade students' literacy skills. The dictionary also contained authentic pictures that could help students to understand the meaning of the words clearly.

\section{REFERENCES}

Abror, M., Suryani, N., \& Ardianto, D. T. (2020). Digital Flipbook Empowerment as A Development Means for History Learning Media. JPI (Jurnal Pendidikan Indonesia), 8(2), 266. https://doi.org/10.23887/jpiundiksha.v8i2.24122

Alam, S. K., \& Lestari, R. H. (2020). Pengembangan Kemampuan Bahasa Reseptif Anak Usia Dini dalam Memperkenalkan Bahasa Inggris melalui Flash Card. Jurnal Obsesi : Jurnal Pendidikan Anak Usia Dini, 
4(1), 284. https://doi.org/10.31004/obsesi.v4i1.301

Alat, Z., \& Dedeoğlu, N. Ç. (2013). Professional Development of Early Childhood Mentor Teachers in Teaching Math. Procedia - Social and Behavioral Sciences, 103(10). https://doi.org/10.1016/j.sbspro.2013.12.244

Allan, D. M., Allan, N. P., Lonigan, C. J., Hume, L. E., \& Farrington, A. L. (2018). The influences of multiple informants' ratings of inattention on preschoolers' emergent literacy skills growth. Learning and Individual Differences, 65. https://doi.org/10.1016/j.lindif.2018.05.014

Batubara, H. H., \& Batubara, D. S. (2020). Penggunaan Video Tutorial Untuk Mendukung Pembelajaran Daring Di Masa Pandemi Virus Corona. Muallimuna: Jurnal Madrasah Ibtidaiyah, 5(2), 21. https://doi.org/10.31602/muallimuna.v5i2.2950

Beck, E., Goin, M. E., Ho, A., Parks, A., \& Rowe, S. (2021). Critical digital literacy as method for teaching tactics of response to online surveillance and privacy erosion. Computers and Composition. https://doi.org/10.1016/j.compcom.2021.102654

Budiman, H. (2016). Penggunaan Media Visual dalam Proses Pembelajaran. Jurnal Pendidikan Islam, 7(2), 171-182. https://doi.org/10.24042/atjpi.v7i2.1501

Candra Lestari, N. P. (2018). Penerapan Model Pembelajaran Kooperatif Tipe Nht Berbantuan Media Audio Visual Untuk Meningkatkan Hasil Belajar IPA. Journal of Education Action Research, 2(4), 355. https://doi.org/10.23887/jear.v2i4.16331

Charles, D., Waldman, M., \& Fink, G. (2018). Measuring early childhood development at a global scale: Evidence from the Caregiver-Reported Early Development Instruments. Early Childhood Research Quarterly, 45. https://doi.org/10.1016/j.ecresq.2018.05.002

Daunic, A. P., Corbett, N. L., Smith, S. W., Algina, J., \& Poling, D. (2021). Efficacy of the social-emotional learning foundations curriculum for kindergarten and first grade students at risk for emotional and behavioral disorders. Journal of School Psychology, 86. https://doi.org/10.1016/j.jsp.2021.03.004

Falloon, G. (2020). From digital literacy to digital competence: the teacher digital competency (TDC) framework. Educational Technology Research and Development, 68(5), 2449-2472. https://doi.org/10.1007/s11423-020-09767-4

Fartina, Hizbi, T., \& Syahidi, K. (2019). Development of Interactive Physics Learning Media Macromedia Flash 8 Based on Straight Motion Material. Journal of Physics: Conference Series, 1539(1). https://doi.org/10.1088/1742-6596/1539/1/012023

Febriansyah, F. E., Ardiansyah, A., \& Darmaji, A. (2020). Cawa Lampung : Kamus Bahasa Indonesia-Lampung Dialek A Berbasis Android. KLIK: Kumpulan Jurnal Ilmu Komputer, 7(3). https://doi.org/10.20527/klik.v7i3.352

Gonzalves, L. (2021). Development of copying skills in L2 adult English learners with emergent print literacy. Journal of Second Language Writing, 51. https://doi.org/10.1016/j.jslw.2021.100790

Greipl, S., Moeller, K., \& Ninaus, M. (2020). Potential and limits of game-based learning. International Journal of Technology Enhanced Learning, 12(4). https://doi.org/10.1504/IJTEL.2020.110047

Hwang, G. J., Wu, P. H., \& Chen, C. C. (2012). An online game approach for improving students' learning performance in web-based problem-solving activities. Computers and Education, 59(4), 1246-1256. https://doi.org/10.1016/j.compedu.2012.05.009

Jessica, V., Halis, A., Ningsi, D. W., Virginia, G. F., \& Syahidah. (2017). Pemberantasan Buta Aksara untuk Peningkatan Kualitas Sumber Daya Manusia Masyarakat Sekitar Hutan Desa Manipi, Kecamatan Pana, Kabupaten Mamasa. Jurnal Ilmiah Pengabdian Kepada Masyarakat, 3(2). https://doi.org/0.29244/agrokreatif.3.2.136-142

Kamelia, K. (2019). Using Video as Media of Teaching in English Language Classroom: Expressing Congratulation and Hopes. Utamax : Journal of Ultimate Research and Trends in Education, 1(1), 34-38. https://doi.org/10.31849/utamax.v1i1.2742

Korat, O., Tourgeman, M., \& Segal-Drori, O. (2021). E-book reading in kindergarten and story comprehension support. Reading and Writing, 0123456789. https://doi.org/10.1007/s11145-021-10175-0

Lau, M. M., \& Li, H. (2019). Whole-day or half-day kindergarten? Chinese parents' perceptions, needs, and decisions in a privatised marketplace. Children and Youth Services Review, 105. https://doi.org/10.1016/j.childyouth.2019.104427

Li, C., Zhang, J., \& Yao, J. (2021). Streamer action recognition in live video with spatial-temporal attention and deep dictionary learning. Neurocomputing, 453. https://doi.org/10.1016/j.neucom.2020.07.148

Lia, L. (2015). Multimedia Interaktif Sebagai Salah Satu Alternatif Pembelajaran dalam Bidang Pendidikan Sains. Jurnal Inovasi Dan Pembelajaran Fisika, 2(2), 132-140. https://doi.org/10.36706/jipf.v2i2.2614

Liang, Q., Torre, J. de la, \& Law, N. (2021). Do background characteristics matter in Children's mastery of digital literacy? A cognitive diagnosis model analysis. Computers in Human Behavior, 122. https://doi.org/10.1016/j.chb.2021.106850

Liyana, A., \& Kurniawan, M. (2019a). Speaking Pyramid sebagai Media Pembelajaran Kosa Kata Bahasa 
Inggris Anak Usia 5-6 Tahun. Jurnal Obsesi: Jurnal Pendidikan Anak Usia Dini, 3(1). https://doi.org/10.31004/obsesi.v3i1.178

Liyana, A., \& Kurniawan, M. (2019b). Speaking Pyramid sebagai Media Pembelajaran Kosa Kata Bahasa Inggris Anak Usia 5-6 Tahun. Jurnal Obsesi: Journal of Early Childhood Education, 3(1). https://doi.org/10.31004/obsesi.v3i1.178

Macaro, E., \& Tian, L. (2015). Exploring teachers' oral explanations of new English lexical items in a Chinese university: Comparisons with dictionary information. 52. https://doi.org/10.1016/j.system.2015.05.002

Mahdi, H. S. (2018). Effectiveness of Mobile Devices on Vocabulary Learning: A Meta-Analysis. Journal of Educational Computing Research, 56(1). https://doi.org/10.1177/0735633117698826

Maijarern, T., Chaiwut, N., \& Nobnop, R. (2018). Augmented reality for science instructional media in primary school. 3rd International Conference on Digital Arts, Media and Technology, ICDAMT. https://doi.org/10.1109/icdamt.2018.8376523.

Majid, M. S. Z. B. A., Ali, M. M. B. A., Rahim, A. A. B. A., \& Khamis, N. Y. B. (2012). The Development of Technical English Multimedia Interactive Module to Enhance Student Centered Learning (SCL). Procedia - Social and Behavioral Sciences, 67, 345-348. https://doi.org/10.1016/j.sbspro.2012.11.337

McCabe, A., Fhailí, S. N. A., O’Sullivan, R., Brenner, M., \& Gannon, B. (2019). Development and validation of a data dictionary for a feasibility analysis of emergency department key performance indicators. International Journal of Medical Informatics, 126. https://doi.org/10.1016/j.ijmedinf.2019.01.015

Muhonen, H., Pakarinen, E., Lerkkanen, M.-K., Barza, L., \& Suchodoletz, A. von. (2020). Patterns of dialogic teaching in kindergarten classrooms of Finland and the United Arab Emirates. Learning, Culture and Social Interaction, 25. https://doi.org/10.1016/j.lcsi.2018.11.011

Nurkancana, W., \& Sunartana. (1992). Evaluasi Hasil Belajar. Usaha Nasional.

O'Brien, B. A., Chin, S., \& Chin, S. (2020). The structure of home literacy environment and its relation to emergent English literacy skills in the multilingual context of Singapore. Early Childhood Research Quarterly, 53. https://doi.org/10.1016/j.ecresq.2020.05.014

Parvareshbar, F., \& Ghoorchaei, B. (2016). The Effect of Using Short Stories on Vocabulary Learning of Iranian EFL Learners. Theory and Practice in Language Studies, 6(7), 1476. https://doi.org/10.17507/tpls.0607.20

Piasta, S. B., Logan, J. A. R., Thomas, L. J. G., Zettler-Greeley, C. M., \& Bailet, L. L. (2021). Implementation of a small-group emergent literacy intervention by preschool teachers and community aides. Early Childhood Research Quarterly, 54. https://doi.org/10.1016/j.ecresq.2020.08.002

Polizzi, G. (2020). Digital literacy and the national curriculum for England: Learning from how the experts engage with and evaluate online content. Computers and Education, 152. https://doi.org/10.1016/j.compedu.2020.103859

Purnama, S., Ulfah, M., Machali, I., Wibowo, A., \& Narmaditya, B. S. (2021). Does digital literacy influence students' online risk? Evidence from Covid-19. Heliyon, 7(6). https://doi.org/10.1016/j.heliyon.2021.e07406

Puspita, P. M., Wirya, N., \& Antara, A. (2016). Penerapan Pendekatan Saintifik Berbantuan Media Kartu Gambar Untuk Meningkatkan Kemampuan Berbicara Di Tk Catur Paramita. Jurnal Pendidikan Anak Usia Dini Undiksha, 4(2). https://doi.org/10.23887/paud.v4i2.7809

Sadaf, A., \& Johnson, B. L. (2017). Teachers' Beliefs About Integrating Digital Literacy Into Classroom Practice: An Investigation Based on the Theory of Planned Behavior. Journal of Digital Learning in Teacher Education, 33(4), 129-137. https://doi.org/10.1080/21532974.2017.1347534

Sari, P. A. P. (2020). Hubungan Literasi Baca Tulis Dan Minat Membaca Dengan Hasil Belajar Bahasa Indonesia. Journal for Lesson and Learning Studies, 3(1), 141-152.

Sehgal, S., Gupt, R., Wlodarski, M., Bilaver, L., Makhija, M., \& Spergel, J. (2021). The Development and Validation of Food Allergy Data Dictionary. Journal of Allergy and Clinical Immunology, 147(2). https://doi.org/10.1016/j.jaci.2020.12.433

Sun, T., Wang, C., Lambert, R. G., \& Liu, L. (2021). Relationship between second language English writing self-efficacy and achievement: A meta-regression analysis. Journal of Second Language Writing, 53. https://doi.org/10.1016/j.jslw.2021.100817

Suryandari, Sajidan, Rahardjo, Prasetyo, \& Fatimah. (2018). Project-Based Science Learning And Pre-Service Teachers' Science Literacy Skill And Creative Thinking. Cakrawala Pendidikan, 37(3). https://doi.org/10.21831/cp.v38i3.17229

Suryani, S. D., Amin, M., \& Rohman, F. (2021). The influence of the research-based monograph book to improve pre-service teachers' knowledge, attitude, and behavior. Jurnal Pendidikan IPA Indonesia, 10(2), 292-302. https://doi.org/10.15294/jpii.v10i2.30180

Tegeh, I. M., \& Kirna, I. M. (2010). Metodelogi Penelitian Pengembangan Pendidikan. Universitas Pendidikan 
Ganesah.

Tong, J., Li, K., Lin, W., Xia, S., Ali, A., \& Jiang, L. (2021). Automatic lumen border detection in IVUS images using dictionary learning and kernel sparse representation. Biomedical Signal Processing and Control, 66. https://doi.org/10.1016/j.bspc.2021.102489

Trisnanti, I. A. N. L., Tirtayani, L. A., \& Putra, I. K. A. (2018). Pengaruh Media Flashcard Bilingual Terhadap Kemampuan Kosakata Bahasa Inggris Permulaan Anak Kelompok B TK Gugus Mawa. Journal Pendidikan Anak Usia Dini Undiksha, 6(3), 346. https://doi.org/10.23887/paud.v6i1.15200

Wong, K. S. R., \& Russak, S. (2020). Hong Kong Cantonese L1 preschool children's name writing in English L2. Cognitive Development, 56. https://doi.org/10.1016/j.cogdev.2020.100957

Wulandari, T. A. J., Sibuea, A. M., \& Siagian, S. (2019). Pengembangan Media Pembelajaran Berbasis Multimedia Interaktif Pada Mata Pelajaran Biologi. Jurnal Teknologi Informasi \& Komunikasi Dalam Pendidikan, 5(1), 75-86. https://doi.org/10.24114/jtikp.v5i1.12524

Wusqo, I. U., Khusniati, M., Pamelasari, S. D., Laksono, A., \& Wulandari, D. (2021). The effectiveness of digital science scrapbook on students' science visual literacy. Jurnal Pendidikan IPA Indonesia, 10(1), 121-126. https://doi.org/10.15294/jpii.v10i1.27130

Zhang, Y., Dai, H., Yun, Y., Lan, A., \& Shang, X. (2020). Meta-knowledge dictionary learning on 1-bit response data for student knowledge diagnosis. Knowledge-Based Systems, 205. https://doi.org/10.1016/j.knosys.2020.106290 